\title{
Surface-Induced Dissociation of Peptide Ions in Fourier-Transform Mass Spectrometry
}

\author{
Evan R. Williams, Kent D. Henry, and Fred W. McLafferty \\ Department of Chemistry, Baker Laboratory, Cornell University, Ithaca, New York, USA \\ Jeffrey Shabanowitz and Donald F. Hunt \\ Department of Chemistry, University of Virginia, Charlottesville, Virginia, USA
}

\begin{abstract}
Peptide molecular ion species up to $m / 23055$ introduced into a Fourier-transform mass spectrometer can be made to undergo extensive fragmentation by electrically floating the ion cell. The proportion of ions dissociated increases with increasing voltage, with $48 \mathrm{eV}$ producing the highest absivlute abundance of fragment ions above $\mathrm{m} / \mathrm{z} 200$. At this energy, spectra closely resemble those from photodissociation at $193 \mathrm{~nm}$, indicating an internal energy deposition of 6-7 eV; change of product abundances with kinetic energy resembles a conventional breakdown curve. The precursor ions apparently are clectrostatically attracted to strike screen wires across the ion cell entrance, producing daughter ions of low kinetic energy. (I Am Soc Mass Spectrom 1990, 1, 413-416)
\end{abstract}

$\mathrm{F}$ ourier-transform mass spectrometry (FTMS) has substantial advantages for the analysis of large molecules [1-5], including multichannel detection over a wide mass range, high resolution $(160,000$ at $\mathrm{m} / \mathrm{z}$ 3200) [5], and the capability for multidimensional mass spectrometry (MS/MS and $\mathrm{MS}^{n}$ ) in the same mass analyzer, which is particularly advantageous for the structural characterization of large linear molecules [6,7]. Collision-activated dissociation (CAD), the most common implementation of MS/MS, has inadequate sensitivity for sequencing peptides of molecular weights $>\sim 2500$ [8-15]; additionally, in FTMS the maximum collision energy decreases with ion mass $[11,16,17]$, and the added gas load decreases FTMS resolution [18].

Alternate methods, such as dissociations with electrons $[19,20]$ and photons $[17,21-24]$, are promising with FTMS. Surface-induced dissociation (SID), pioneered by Cooks and co-workers [25-30], has several attractive advantages. A relatively narrow range of internal energies is deposited; this can be varied by changing the collision energy [29] $(200 \mathrm{eV}$ collisions even dissociate anthracene molecular ions into $C_{2}-C_{4}$ fragments [30]). Other advantages included no added gas load and the certainty of a single surface collision; adding energy to an ion with stepwise collisions can allow isomerization between collisions. However, reported SID efficiencies are relatively low $(\sim 5 \%)$ [28]. Surface induced dissociation of peptide ions using a microchannel plate [31] and of those up to $m / z 1300$ has been reported recently [27]. Surface-induced dissociation has been effected in a Fourier-transform mass

Addregs correspondence to Fred W. McLafferty, Department of Chemistry, Baker Laboratory, Cornell University, Ithaca, NY 14853-1301.

spectrometer; ions formed in one cell of a dual ion cell are accelerated into the other cell for SID [32], or orbiting ions are made to collide with a trapping plate [33]. Here, an alternative method is described for ions introduced from an exterior source.

\section{Experimental}

On the tandem quadrupole Fourier-transform mass spectrometer with a 7-T magnet used previously $[34,35]$, the back trapping plate of the FTMS cell was replaced by one of solid copper. The cell is floated electrically by a variable $D C$ offset, $V_{C E L L}$, on the receive and excite plates that are capacitively decoupled from their corresponding amplifiers [36]. Trapping plate potentials are floated to $V_{\text {CELI }}$ during SID ion formation (4 ms), then pulsed to a variable positive potential $(+3-+8.7 \mathrm{~V})$ relative to $\mathrm{V}_{\mathrm{CELL}}$. All DC voltages were supplied by batteries.

$\mathrm{A} \mathrm{Cs}^{+}$gun (10 kV, $5 \times 10^{-8}$ amps, $4 \mathrm{~ms}$ pulse) produces secondary ions from the sample $(0.5 \mu 1$ of 100 pmole $/ \mu$ l solution, $5 \% \mathrm{CH}_{3} \mathrm{COOH} / 0.1 \% \mathrm{CF}_{3} \mathrm{COOH}$, in 3:1 thioglycerol/glycerol) on a probe tip at $+1 \mathrm{~V}$. The ions are introduced to the FTMS cell through two RFonly quadrupoles, $-25-\mathrm{V}$ DC offset, with low-mass cutoff adjusted to pass only molecular ion species. Ions are accelerated (above the 1-eV probe) into the floated cell through a mesh ( $90 \%$ optical transmittance) over the trap-plate entrance. Spectra were collected using $2.6 \mathrm{MHz}$ bandwidth, $16 \mathrm{~K}$ data points ( $32 \mathrm{~ms}$ total time per scan). The cell pressure was $\sim 10^{-9}$ torr. For photodissociation $193 \mathrm{~nm}$ photons were introduced [23] from a Lumonics excimer laser (ArF, $\sim 10^{-6} \mathrm{~J}$ per 10 ns pulse) through the conventional mesh entrance of the back trapping plate. 
RSBP (MW 3054), a 29 residue peptide, was generated by digesting rabbit sex-steroid-binding protein using the enzyme endoproteinase Asp- $N$, followed by separation by reverse-phase high-performance liquid chromatography on a $\mathrm{C}_{18}$ column [37]. The other peptides were similarly purified.

\section{Results and Discussion}

Ions are introduced from the exterior source through the mesh ( $90 \%$ optical transmittance) on the front trapping plate toward the solid back trapping plate. Using only the $\sim 1 \mathrm{eV}$ acceleration energy of the floated probe, substance $P$ (MW 1347) ions produce (Figure 1, top) mostly $[\mathrm{M}+\mathrm{H}]^{+}$ions with few fragments; fragment ions formed in the source are removed by the RF quadrupoles, and CAD should be negligible at the $10^{-9}$ cell pressure [17]. However, accelerating these ions by floating the cell to $-47 \mathrm{~V}$ (Figure 1, middle) produces extensive fragmentation. Little of this should be due to CAD by gases desorbed from the mesh [38]; no change in the spectrum was noted with repeated ion bombardment of the mesh, and for deliberate CAD spectra the efficiency and degree of dissociation are much smaller $[17,39]$. Raising the potential of the back trapping plate to $+10 \mathrm{~V}$ (which should prevent the primary ions from colliding with this surface) with the front trap at $-23 \mathrm{~V}$ (and pulsed to $-15 \mathrm{~V}$ for trapping), and with the excite/receive plates at -47 $V$, yielded approximately the same ion abundances as those with the cell at $-23 \mathrm{~V}$, but with slightly lower signal-to-noise (S/N) ratio. This is consistent with dissociative collisions occurring at the front mesh, but not

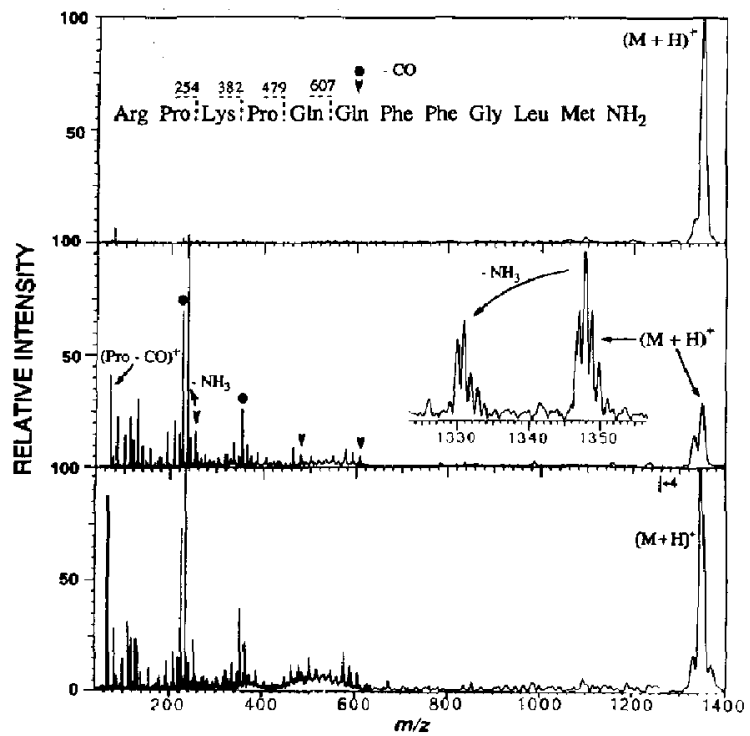

Figure 1. Mass spectrum (100 scans) of substance P (MW 1347), excluding ions of $m / z<1300$, with cell at ground (top; both trapping plates pulsed) and floated to $-47 \mathrm{~V}$ (middle; inset, molecular ion region, 128K broadband spectrum), and from $193 \mathrm{~nm}$ photodissuciation (bottom). at the back trapping plate; for all compounds examined most peaks correspond to fragmentations expected for the precursor ions. Increasing the trapping potentials above a few volts did not improve the ion trapping efficiency $[23,34,35]$; apparently the high negative potential of the individual screen wires attracts the positive ions for collisions [40], with few ions leaving the surface with sufficient $z$-axis energy to undergo dissociation at the back trapping plate.

Energy Deposition. The substance $\mathbf{P}$ spectrum shows large $\left[\mathrm{M}+\mathrm{H}-\mathrm{NH}_{3}\right]^{+}$and characteristic $\mathrm{N}$-terminal fragments containing up to five amino acids, without and with the loss of $\mathrm{CO}$ and $\mathrm{NH}_{3}$. For comparison, the same $[\mathrm{M}+\mathrm{H}]^{+}$ions were photodissociated using low flux (single photon absorbed) $193 \mathrm{~nm}(6.4 \mathrm{eV})$ photons. These spectra (Figure 1) are closely similar, indicating that the internal energy deposited is $\sim 6.4 / 48=13 \%$ of the laboratory collision energy; Cooks and co-workers $[27,28]$ have found values of $13-16 \%$ for SID up to 100 $\mathrm{eV}$. As they have also shown [25-30], changing the collision energy changes ion intensities similar to that of a breakdown curve (Figure 2; the possible second maximum for the $m / z 70$ at $10-20 \mathrm{eV}$ could be due to high experimental error). The internal energy deposited is far greater than that for multikilovolt CAD spectra of substance $P$, which show $m / z 1002$ as the base peak and $m / z 354$ as $20-54 \%$ [39]. Surprisingly, the total ion yield goes through a decp minimum at $10-20 \mathrm{eV}$. This could be due to increased neutralization or to the DC offset of the quadrupole $(-25 \mathrm{~V})$ attracting ions after collision away from the cell when it is floated at a less negative potential, but these were not tested.

Efficiency. As a further unexpected result for $48 \mathrm{eV}$ collisions, the sum of daughter ion intensities is actually 1.3 times that of $[\mathrm{M}+\mathrm{H}]^{+}$without SID $(4.7 \times$ with both traps pulsed). This could arise from higher detec-

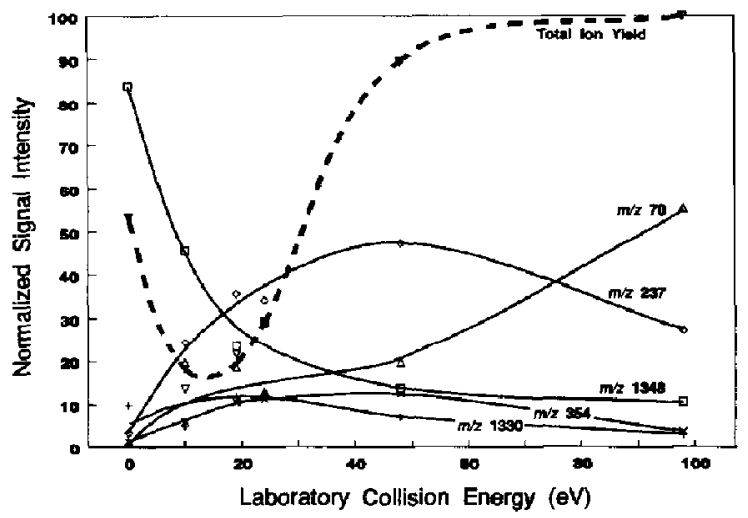

Figure 2. Effect of SID energy on the formation of $\square=[M+$ $\mathrm{H}]^{+},+=\left[\mathrm{M}+\mathrm{H}-\mathrm{NH}_{3}\right]^{+}(\mathrm{m} / \mathrm{z} 1331), x=(\text { Arg-Pro-Lys }-\mathrm{CO})^{+}$ $\left(x\right.$ 10) $\left(m / z\right.$ 354), $\diamond=\left(\text { Arg-Pro }-\mathrm{NH}_{3}\right)^{+}(m / z 237)$, and $\Delta=$ (Pro $-\mathrm{CO}^{+}(m / z 70)$ from substance $P$, both trapping plates pulsed. With only the front trap plate grounded for ion introduction without SID, the $[\mathrm{M}+\mathrm{H}]^{+}$intensity is $\sim 300$. 
tion efficiency for low mass ions $[17,41]$ and to more efficient trapping by the cell's deep electrostatic sink. These hard collisions appear to remove most of the ion kinetic energy along the z-axis; raising the trapping potential from $+3 \mathrm{~V}$ to $+8.7 \mathrm{~V}$, relative to the cell voltage, has a negligible effect on the SID spectrum. Further, the back trapping plate does not need to be left at the trapping potential when that on the front trapping plate is pulsed down to admit ions, as is necessary with the cell grounded. Trapping could be aided additionally by the collisional conversion of $z$ axis kinetic energy into orbital motion in the $x, y$-axis; for high mass fragment ions this kinetic energy is removed efficiently by collisional relaxation [42].

Structural infomation. Surface-induced dissociation of three other oligopeptides also caused extensive fragmentation, with 48-eV collisions producing the highest absolute abundance of fragments above $m / z 200$ (Figure 3). With porcine renin substrate tetradecapeptide, two overlapping sets of N-terminal fragments correspond to initial cleavage at proline and histidine and provide sequence information for six of the sixteen amino acids. The SID spectrum of rat atriopeptin-III only shows losses of 113 and 114 mass units (Leu or Ile, Asn); the disulfide linkage could be interfering with formation of the usual sequence peaks. RSBP, the largest peptide studied, produced a weak $\left[\mathrm{M}+\mathrm{H}^{+}\right.$ signal at $m / z 3055$, but the SID spectrum is similar to that produced by $193 \mathrm{~nm}$ photodissociation [23]. N-terminal fragments corresponding to cleavage at three proline groups provide information on thirteen amino acids, but not on their relative chain positions. Collision-activated dissociation of oligopeptides this large is usually not possible [7]. To improve the undesirable degree of fragmentation, the trapping efficiency at lower collision energies could be improved

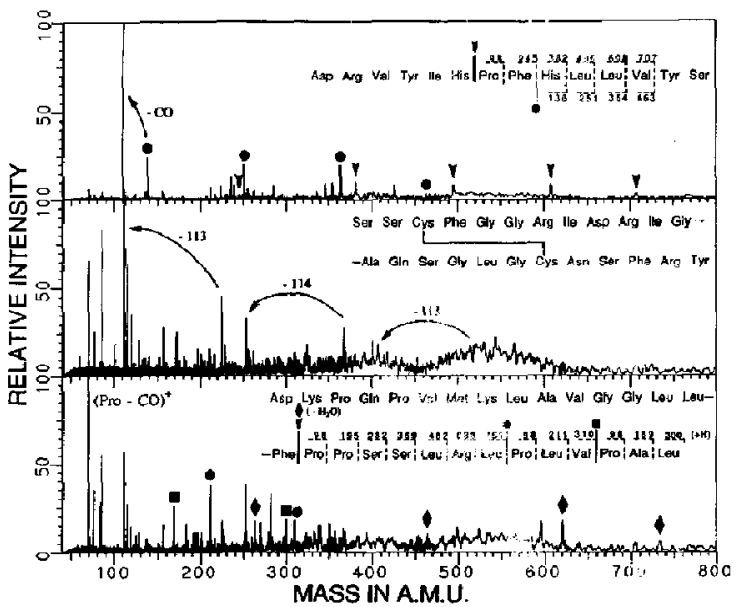

Figure 3. $48 \mathrm{eV}$ SID spectra of renin substrate tetradecapeptide (MW 1758, 100 scans), atriopeptin III (MW 2549, 200 scans), and RSBP (MW 3054, 200 scans) (top to bottom). by using either a grounded second screen just after the quadrupole rods or the back trapping plate as a collision surface. No reactive collisions with the surface were observed $[27,43]$.

\section{Conclusions}

Surface-induced dissociation provides high collision energy, independent of mass, making sequencespecific dissociations possible for large ions in FTMS, even those of $m / z>3000$, where CAD provides litthe structural information. Surface-induced dissociation efficiency and fragmentation extent are high, similar to those of $193 \mathrm{rm}$ photodissociation, but its costs are substantially lower; it should offer a mechanism in addition to $\mathrm{CAD}$ [44] for dissociating large multiply protonated ions formed by electrospray [44-46]. Neutralization will also deposit energy equivalent to the ionization of the corresponding neutral minus the work function of the metal, or $\sim 1 \mathrm{eV}$ using a stainless steel target (>3 eV for a $\mathrm{Cs}$ target); this could produce nonergodic dissociations at high proton-affinity sites yielding two ionic products [47]. With a dual-cell configuration [48], SID has also been effected by accelerating ions formed in one cell into the adjacent celI to collide with the opposite trapping plate $[32,47]$; a pulsed voltage on a screen between the cells should also be effective. This has the advantage that a multiplicity of parent ions can be selected and simultaneously dissociated using the Hadamard deconvolution method [49].

\section{Acknowledgment}

The authors are indebted to R. E. Hein, P. Martino, and B. H. Wang for experimental help and/or advice, and to $C$. L. Wilkins for prepublication information (ref 33). The research at Cornell has been generously supported by the National Institutes of Health (grant GM-16609), with instrumentation by the National Science Foundation (grant CHE-8616907) and the Gavlin Fund, and at the University of Virginia by the National Science Foundation (grant CHE-8618780).

\section{References}

1. Comisarow, M. B.; Marshall, A. G. Chem. Phys, Lett. 1974, $25,282-283$.

2. Fourier Transforn Mass Spectrometry; Evolution, Innovation, and Applications; Buchanan, M. V., Ed.; American Chemical Society Symposium Series, No. 359; Washington, D.C., 1987.

3. Wilkins, C. L.; Chowdhury, A. K.; Nuwaysir, L. M.; Coates, M. L. Mass Spectrom. Rev. 1989, 8, 67-92.

4. Cody, R. B.; Kinsinger, J. A.; Ghaderi, S.; Amster, I. J.; McLafferty, F. W.; Brown, C. E. Anal. Chim. Acta 1985, 178, 43-66.

5. Ijames, C. F.; Wilkins, C. L. I. Am. Chem. Soc. 1988, 110, 2687-2688.

6. Tandent Mass Spectrometry; McLafferty, F. W., Ed.; Wiley: New York, 1983.

7. Busch, K. L.; Glish, G. L.; McLuckey, S. A. Mass Spectrometry/Mass Spectrometry; VCH Publishers: Deerfield, FL, 1988.

8. Biemarn, $K_{,}$; Martin, S. A. Mass Spectrom. Rev. 1987, 6, 1-76. 
9. Hunt, D. F.; Shabanowitz, J.; Yates, J. R. III; Griffin, P. R.; Zhu, N. Z. In Methods in Protein Sequence Analysis; Wittmann-Liebold, B., Ed; Springer Verlag: New York, 1989; pp 183-190.

10. Cody, R. B.; Amster, I. J.; McLafferty, F. W. Proc, Natl. Acad. Sci., USA 1985, 82, 6367-6370.

11. Yang, L.-C.; Wilkins, C. L. Org. Mass Spectrom. 1989, 24, 409-414.

12. Neumann, G. M.; Derrick, P. I. Org. Mass Spectroth, 1984, 19, 165-170.

13. Kiplinger, J. P.; Bursey, M. M. Org- Mass Spectrom. 1988, 23, 342-349.

14. Terklenburg, R. F. Jr.; Miller, M. N.; Russell, D. H. I. Am. Chem. Soc. 1989, 111, 1161-1171.

15. Alexander, A. J.; Thibault, P.; Boyd, R. K. J. Am. Chem. Soc $1990,112,2484-2491$.

16. Cody, R. B.; Freiser, B. S. Anal. Chem. 1982, 54, 1431-1433.

17. Williams, E. R.; Furlong, J. J. P.; McLafferty, F. W. I. Am. Soc. Mass Spectrom. 1990, 1.

18. White, R. L.; Ledford, E. B. Jr.; Ghaderi, S.; Wilkins, C. L.; Gross, M. L. Anal. Chem. 1980, 52, 1527-1529.

19. Cody, R. B.; Freiser, B. S. Anal. Chem. 1987, 59, 1054-1056.

20. Wang, B.; McLafferty, F. W. Org. Mass Spectrom., accepted.

21. Dunbar, R. C. In Gas Phase Ion Chemistry; Bowers, M. T., Ed.; Academic: Orlando, 1984; pp 129-166.

22. Hunt, D. F.; Shabanowitz, J.; Yates, J. R. III I. Chem. Soc. Chem. Commun. 1987, 548-550.

23. Hunt, D. F.; Shabanowitz, J.; Yates, J. R. III; Griffin, P. R.; Zhu, N. Z. Anal. Chim. Acta. 1989, 225, 1-10.

24. Nuwaysir, L. M.; Wilkins, C. L. Anal. Chem. 1989, 61, 689-694.

25. Mabud, Md. A.; DeKrey, M. J.; Cooks, R. G. Int. J. Mass Spectrom. Ion Proc. 1985, 67, 285-294.

26. Pachuta, S. J.; Kenttamaa, H. I.; Sack, T. M.; Cerny, R. L.; Tomer, K. B.; Gross, M. L.; Pachuta, R. R.; Cooks, R. G. J. Am. Chem. Soc. 1988, 110, 657-665.

27. Bier, M. E.; Schwart2, J. C.; Schey, K. L.; Cuoks, R. G. Int. I. Mass Spectrom. Ion Proc, accepted.

28. Bier, M. E.; Amy, J. W.; Cooks, R. G.; Syka, J. E. P.; Ceja, P.; Stafford, G. Int. J. Mass Spectrom. Ion Proc. 1987, 77, 31-47.

29. DeKray, M. J.; Kenttammaa, H. I.; Wysocki, V. H.; Cooks, R. G. Org. Mass Spectrom. 1986, 21, 193-195.

30. Schey, K.; Cooks, R. G.; Grix, R.; Wollnik, H. Int. J. Mass
Spectrom. Ion Proc. 1987, 77, 49-61.

31. Aberth, W, 36th ASMS Conference on Mass Spectrometry and Allied Topics, San Francisco, CA 1988, pp 73-74.

32. McLafferty, F. W.; Williams, E. R. Proc. 1986 Conf. Chemical Defense Res., Aberdeen Proving Ground, MD, 1987.

33. Ijames, C. F.; Wilkins, C. L., private communication, January 15, 1990.

34. Hunt, D. F.; Shabanowitz, J.; McIver, R. T. Jr.; Hunter, R. L.; Syka, J. E. P. Anal. Chem, 1985, 57, 765-768.

35. Hunt, D. F.; Shabanowitz, J.; Yates, J. R. III; Zhu, N.-Z.; Russell, D. H.; Castro, M. E. Proc. Natl. Acad. Sci. 1987, 84, 620-623.

36. Smalley, R. F., personal rommunication, 1988.

37. Griffin, P. R.; Kumar, S.; Shabanowitz, J.; Charbonneau, H.; Namkung, P. C.; Walsh, K. A.; Hunt, D. F.; Petra, P. H. I. Biol. Chem. 1989, 264, 19066-19075.

38. Kim, M. S.; McLafferty, F. W. J. Am. Chem. Soc. 1978, 100, 3279.

39. Gross, M. L. In Methods in Enzymology; McCloskey, J. A., Ed.; Academic: San Diego 1990.

40. Grix, R.; Kutscher, R.; Li, G.; Gruner, U.; Wollnik, H. Rapid Commun. Mass Spectrom. 1988, 2, 83-85.

41. Hanson, C. D.: Castro, M. E.; Russell, D. H. Anal. Chem. 1989, 61, 2130-2136.

42. Williams, E. R.; Henry, K. D.; McLafferty, F. W. J. Am. Chem. Soc., accepted.

43. Ast, I'; Mabud, Md. A.; Cooks, K. G. Int. J. Mass Spectrom. Ion Proc. 1988, 82, 131-150.

44. Smith, R. D.; Loo, J. A.; Barinaga, C. J.; Edmonds, C. G.; Udseth, H. R.; J. Am. Soc. Mass Spectrom. 1990, 1, 6671.

45. Fenn, J. B.; Mann, M.; Meng, C. K.; Wong, S. F.; Whitehouse, C. M. Science 1989, 246, 64-71.

46. Henry, K. D; Williams, E. R.; Wang, B. H.; McLafferty, F. W.; Shabanowitz, J.; Hunt, D. F. Proc. Natl. Acad. Sci., USA 1989, 86, 9075-9078.

47. McLafferty, F. W.; Amster, I. J.; Furlong, J. J. P.; Loo, J. A.; Wang, B. H.; Wulliams, E. R. In Fourier Transform Mass Spectrometry; Buchanan, M. V., Ed.; American Chemical Society Symposium Series, No. 359; Washington, D.C., 1987.

48. Chaderi, S.; Littlejohn, D. P. Adv. Mass Spectrom. 1986, 70, 875.

49. Williams, E. R.; Loh, S. Y.; McLafferty, F. W.; Cody, R. B. Anal. Chem. 1990, 62, 698-703. 